\title{
De „47“.
}

Da Navnene paa de 47 danske Sønderjyder, der forst i September 1866 overbragte Kong Wilhelm af Preussen en Adresse for at takke ham for den i Fredsvilkarene fra Nicolsburg optagne Bestemmelse om Nordslesvigs Gjenforening med Dammark paa Grundlag af en fri Folkeafstemning, saa vidt vi ved, ikke findes aftrykte noget Steds, gjengives the her tilligemed Ordlyden af den Adresse, de overbragte:

Allerdurchlauchtigste, stormegtigste, allernaadigste Arveherre ogr Konge!

Fredspræliminairerne i Nicolsborg og Deres Majestæts Ord til Deres Landdag: „at Deres Majestat, saafremt Befolkningen i de nordlige Distrikter af Hertugdømmet Slesvig skulde udtale sig derfor ved fri Afstemning, er villig til atter at aftræde disse Distrikter til Danmark, have givet os som danske Slesvigere Mod til at henvende os til Deres Majestæt med Tak og med B $s$ n on vore dyrebareste Onskers Opfyldelse, og vi have folt os forpligtede til at foretage dette Skridt saameret desmere, da vi fra alle Sider. fia Efterretning om Adresser til Deres Majestæt fra et lille Parti, som sandelig ikke er berettiget til at tale i hele Befolkningens Navn.

\section{Allernaadigste Konge!}

I det Øieblik, da Tydskland ved den Preussiske Armees Seire og Deres Majestrets vise og kloge Politik er gjen- 
givet sig selv til national Gjenfulelse, vore ri i en haadt provet Befolknings Navn, hris Skjabne nu af Forsynet er layt i Deres Majestrets Haand, at narme os Deres Majestats Throne for at ultale vort Ifaab og ror Fyget.

Omend ri liun mole her Faa i Tal og dog tillade os at tale $i$ den hele dansk-slesvigske Befollinings Narn, da skeer det deols for at undgate endog Slimnet af Agitation, deels fordi vi ere fuldstændig overberiste om, at, ligesom vi selv hore lijemme i alle Nordslesvigs Eone, salaledes ultale vi ogsaa kun det, der rorer sig i Brystet hos Befolkningens overveiende Fleertal ligefra liongeaaen til sonder for Flenshorg, hilken sidste I'aastand vi fortroste os til at berise ved Tusinder af Cinderskrifter.

Vi fole los os selv dybere end nogen sinde tilforn, at vi aldrig ville kunne urlvikle os frit og naturligt undtagen i Forening med vort Moderland Danmark, til hrilket vi lave varet knyttede salangt Historien naer, og med hrilket vi hiltil forenet vod falles Minder, falles Historie ogr ligeartet Lilviklingr, have fort det lykkeligste Samliv. Deres Majestot vil derfor ei fortornes, nuar vi i dybeste Lnderdanighed ultale, at vi altid lave anseet det for en fulcstandig aandelig Tilintetgjorelse, naar det Oieblik forst var inltradt, at vi klulde trade i Forbindelse med en Stat, med hvilken vi ikke have nogetsomlielst andeligt Baand tilfalles, ligesom Deres Majestat ograa vil kumne fatte den inderlige Glade, som greb den liele dansk-slesvigske befolkning ved Efterretningen om, at Deres Majestret hojmodlig vilde give os tilbage til det Land, som vi ene og alene ere istand til at kalde vort Fædreland.

$\mathrm{Vi}$ hengive os til det Haab, at I)res Majestat vil tıafte en Afgurrelse, der til samme Tid er hrojliæertet og 


$$
\text { De }{ }_{n} 47^{*} \text {. }
$$

statsklog, der vil bane Veien til evig Fred og naborenskiabeljyt Forhold mellem waheslapgtede Folliestammer, og at Deres Majestæt vil sætte Kronen paa den store Daad, Forsynet har lagt i Deres Majestats Hiender, derved, at De hoimodig tillader Befolkningen at yttre sign on at bestemme sin Skjabne i et saadant Onfang, at Alt, hvad der utvivlsomt nærer onsket om at komme tillage til Danmark, bliver adspurgt.

Ti nedivede Himlens Velsignelke over Deres Majestat! $\mathrm{Vi}$ hede, at den Hoieste ril slijænke Ieres Majestact Visdom til at skale Lylike og Velsignelse for en Befolkning, som uden dette imodeseer sin andelige Dod.

Allerunderdanigst

$$
\text { N. Ahlmann, }
$$

Deputationens Ordforer.

Defutationens Medlemmer rare:

Flemsorg by:

Kjubm. Detlefsen.

Glasfabrikant Jensen.

Ijjolm. Hoek, dep. Borger. Garver J. l'laetner, do.

Kjolbm. l'etersen, do.

Flensborg Amt:

Bruhn, Munkvolstrup.

Lorenzen, Grumtofte.

Brodersen, Hyrup.

Andresen, Frosler.

Nielsen, Veibæk.

Kmmrd. Schmidt, Kollund.

A abenraa Amt:

Farrer Jürgensen, Gratasteen. $\mid$ Garver Blscker.
Sundered:

Farver Hansen, cllerup.

Inller Comrissen, Nybul.

Lwrents I'etersen, Ragebol.

Als:

Jernsthher Petersen, Sunderborg.

Slagtermester Reimers, do.

Propr. Alılmann, Augustenborrg.

Hans Lassen, I,ysabild.

Consul With, Nordlorg.

Haderslev By:

Skomager Simonsen. 
Haderslev Amt:

J. P. Friis, Eisuol.

Iver Friis, Fredsted.

Andr. Juhl: Kjelstrup.

N. Steffensen, Styding.

Wildfang, Bæk.

Nissen, Lunding.

Scherrebeck, Djernas.

P. Skau, Bukshave.

Bjerrum, Skjærbxk.

Jens Jannichsen, Barsbøl.

B. Refslund, Bovlund.

Appel, Rangstrup.

Linudsen, Midtgaard.

Osster, Christiansfelt.
Tonder og Logumkloster Amter:

Knudsen, Troiborg.

Terkelsen, Skads.

Jeggersen, Emmerlev.

Nicolaisen, Ballum.

Kjøbm. Bertelsen, do.

A. 'T. Hansen, Randerup.

Boesen, Medolden.

Clausen. Bansholm.

Clausen, Sønder Vollum.

Moller, Dostrup.

Rosenbom, Logumkloster. 